\title{
A Framework for Green Supply Chain Management in the Construction Sector: A Case Study in Indonesia
}

\author{
I. Putu Artama Wiguna ${ }^{1}$ (D), Farida Rachmawati ${ }^{1}$ (D), M. Arif Rohman ${ }^{1}$ (iD, Larashati B'tari Setyaning ${ }^{2}$ iD \\ ${ }^{1}$ Institut Teknologi Sepuluh Nopember (Indonesia) \\ ${ }^{2}$ Universitas Muhammadiyah Purworejo (Indonesia) \\ artama@ce.its.ac.id,farida.rachmawati@gmail.com,ari@ce.its.ac.id, btari.larashati@gmail.com
}

Received: December 2020

Accepted: September 2021

\begin{abstract}
:
Purpose: In order to implement green supply chain management (GSCM) to support the effort in reducing the environmental impact of the supply chain processes, a framework needs to be developed. This study aimed to propose a conceptual and holistic GSCM framework that represents a roadmap towards GSCM implementation by integrating all green supply chain practices by various stakeholders of the construction sector in Indonesia.

Design/methodology/approach: Green supply chain management practices were obtained from an extensive literature review. A questionnaire survey of GSCM stakeholders in the construction sector was conducted to obtain the preference regarding green supply chain variables as the proxy for variable weighting and ranking. Pairwise comparison (PWC) and technique for others preference by similarity to ideal (TOPSIS) were adopted to analyze the weight and to rank the green practices, respectively. The findings from the PWC and TOPSIS were used to develop the framework.

Findings: The framework for GSCM in the construction sector in Indonesia primarily focuses on reducing the use of hazardous materials, the management of waste at the project site, selling products and components that are no longer used, using video conferencing both inter- and intra-organization meetings, and support from the management level in the form EMS and ISO 14001 certification.
\end{abstract}

Research limitations/implications: This study did not include other GSCM performances as criteria, such as operational and logistical performance.

Practical implications: An efficient evaluation technique developed through the framework could be used in decision making policies by policy makers and organizational stakeholders that can identify and prioritize the green practices for adoption of GSCM in the construction sector.

Social implications: A good framework can connect the benchmarking concept with practical applications because the framework can guide organizations in adopting and implementing benchmarking activities more systematically, comprehensively, and in a timely manner

Originality/value: The originality of this research is that the GSCM framework was developed with most relevant green practices based on ranking and weighting criteria, as well as the preferences of the main stakeholders.

Keywords: GSCM, framework, construction sector, PWC, TOPSIS 


\section{To cite this article:}

Wiguna, I.P.A., Rachmawati, F., Rohman, M.A., \& Setyaning, L.B. (2021). A framework for green supply chain management in the construction sector: A case study in Indonesia. Journal of Industrial Engineering and Management, 14(4), 788-807. https://doi.org/10.3926/jiem.3465

\section{Introduction}

Sustainability is a major issue for the majority of industries. Climate change and environmental pollution have been some of the greatest concerns for businesses and governments, driving them to evaluate the environmental impacts of their activities (Nurunnabi, 2016). Green Supply Chain Management (GSCM) integrates environmental factors into conventional supply chain management, starting from the process of design, material purchasing, production, distribution, through to end-of-life management (Zhu, Sarkis \& Geng, 2005). According to Shipeng (2011), GSCM pays attention to environmental factors in every supply chain activity, both upstream (suppliers) and downstream (consumers). Therefore, activities in GSCM involve several organizations that are stakeholders in every supply chain activity (Zhu, Sarkis, \& Lai, 2008). Collaboration between departments in the organization and cooperation between organizations in the application of green concepts at each stage of the supply chain characterize the effective implementation of GSCM.

GSCM implementation provides several environmental benefits, such as reducing carbon emission levels, increasing reused and recycled materials, reducing the use of hazardous materials, saving energy usage, and reducing waste production (Balasubramanian \& Shukla, 2017; Zhu et al., 2005). In addition, cost reduction is the most important benefit (Hervani, Helms \& Sarkis, 2005). Costs will decrease in operational activities in both the manufacturing and construction sectors if changes toward green strategies are broadly and effectively made (Ali, Saad, Sabir, Muhammad, Salman \& Zeb, 2019). Therefore, GSCM implementation can positively influence an organization's economic performance, such as increased sales, market share, and profits (Alvarez, Jimenez \& Lorente, 2001; Laari, Teoyli, Solakivi \& Ojala, 2016; Zhu \& Sarkis, 2004). To improve the economic and environmental performance, the organizational performance, which can provide a long-term and complete picture of the benefits of implementing green practices (Green et al., 2012), must be considered (Zhu \& Cote, 2004). The construction sector needs to implement GSCM as the negative impact on the environment caused by this sector is quite large. Globally, the construction sector produces one-third of total carbon emissions, one-third of total energy use, one-fourth of water use, and $40 \%$ of waste (UNEP-SBCI, 2016). Therefore, the construction sector needs to consider implementing GSCM. According to Shurrab, Hussain and Khan (2018), the implementation of the green concept in the construction sector, especially building projects, is still focused on the green design component, such as efforts to minimize energy use and increase comfort. A good framework could connect the benchmarking concept with practical applications, because the framework could guide organizations in adopting and implementing benchmarking activities more systematically, comprehensively, and in a timely manner. Deros, Yusof and Salleh (2006), defined a framework as a simplified set of theoretical principles and practical guidelines for carrying out the implementation and adoption of benchmarking to increase the chance of success, which is easy to understand, efficient, and can be implemented within a reasonable cost and time.

This study was conducted in the East-Java province, Indonesia. Indonesia is an emerging economic country, for example, there were 233 planned public infrastructure projects in 2014 - 2019 (Bappenas, 2014). Thus, there are potential sustainability issues, especially related to green supply chain management problems. The majority of past studies have focused on GSCM implementation on manufacturing or general industry (Mohanty \& Prakash, 2013; Zaid, Jaaron, Talib \& Abdul, 2018) and construction projects, including green design, purchasing, supplier, innovation, and operation (Saputra, 2015; Hardiani, 2016; Le, 2020). However, the stakeholders and green practices are partial and disjointed, as they only involved contractors and consultants (Zulfikar, 2020), Wibowo, Handayani and Mustikasari (2018), examined a GSCM framework using five dimensions based on life cycle, while Ali et al. (2019), ranked six alternatives of GSCM practices using fuzzy TOPSIS. GSCM studies in construction sector have 
also been conducted in some emerging economic countries, such as Pakistan (Ali et al., 2019), UAE (Balasubramanian \& Shukla, 2017), Indonesia (Wibowo et al., 2018), and India (Singh \& Misra, 2020). However, some previous studies (Balasubramanian \& Shukla, 2017) did not provide a ranking, as they provided factors that correlated with using Structural Equation Model (SEM). A study related framework that represents a holistic roadmap towards GSCM implementation along with green practices and stakeholders is required.

Therefore, this study aimed to develop a holistic GSCM framework for the construction sector in Indonesia. This involved the main stakeholders at the project site, namely, the owner, design consultant, contractor, and supplier. This study also provides weighting and ranking for the GSCM practices and all relevant stakeholders. The integration of stakeholders and technologies is an important part of the supply chain management (Budiarto, Prabowo \& Herawan, 2017).

First, this paper provides a theoretical perspective of the related concepts followed by the research methods and case study description. The theory and case study are then compared, based on the questionnaire survey completed by respondents from construction companies. The recommendations are summarized based on the theory and data analysis results. Finally, the conclusions and implications for future research are stated.

\section{Supply Chain Management (SCM) and Green Supply Chain Management (GSCM)}

The supply chain is a combination of all company activities to meet consumer needs, involving transformation and flow of products from raw materials to end consumers and is accompanied by the flow of information and money (Li, 2007). A series of activities in the construction sector supply chain include planning, design, and production on-site (Winch, 2010). Compared to supply chains in other sectors, the supply chain in the construction sector is more complicated, diverse, and fragmented because it involves many stakeholders (Rezgui \& Miles, 2009). Supply chain management is very important in company operations because it includes all elements that participate and integrates all activities ranging from the purchasing of raw materials to distribution to consumers and managing labo5r shortages, and the scarcity of construction materials and equipment (Cooper, Douglas, Martha \& Pagh, 1997; Simatupang \& Sridharan, 2016). Success factors in the construction supply chain include communication, trust in suppliers, and risk allocation; thus, there is a need for effective communication with suppliers to increase trust, scheduled discussions to highlight problems experienced by suppliers during the project's life cycle, and formation of a risk management team involving suppliers (Abas, Khattak, Tufail \& Nadir 2020).

GSCM is a concept that incorporates environmental considerations into conventional SCM (Zhu, Geng \& Lai, 2011), into both upstream and downstream activities (Shipeng, 2011). According to Jung (2011), GSCM is part of the efforts to integrate environmental parameters with SCM. A green construction project could be achieved when all stakeholders implement whole or partial green practice in every single stage of supply chain, starting from the design phase through to end-of-life management; thus, stakeholders must be able to cooperate and align each other's interests (UN Global Compact, 2010).

Efforts to "green" supply chains in the construction sector require the involvement of all supply chain stakeholders. Therefore, the inability of one of the stakeholders to fulfill these efforts to be more environmentally friendly can affect the entire business at all stages of the supply chain. Although the construction sector has different characteristics compared to other sectors, management ideas and best practices from those sectors, such as GSCM, can still be applied (Harty, 2008). The advantages of implementing GSCM are reducing costs through reducing material purchases and energy consumption, integrating suppliers in decision-making processes that support green innovation, growing market share, and increasing profits (Bowen, Cousins, Lamming \& Faruk, 2001; Zhu \& Sarkis, 2004).

\subsection{Green Supply Chain Management Practices}

Every activity carried out by companies can have a negative impact on the environment, which is why companies apply GSCM practices (Balasubramanian \& Shukla, 2017). Companies need to implement green practices in the production process and supply chain to reduce environmental impacts (Roztamzadeh, Govindan, Esmaeili \& Sabaghi, 2015) because the environment is affected at every phase of production process (Walker, Sisto \& Bain, 2008). GSCM practices can be divided into several practices based on previous studies with GSCM in the 
construction sector topic. Balasubramanian and Shukla (2017) categorized GSCM practices into green design, purchasing, transportation, construction, as well as end-of-life management. Shurab et al. (2018) divided GSCM practices into green practices, energy and water saving, facilitating green practices, environmental training, and green purchasing. Ali et al. (2019) divided GSCM practices into green design, procurement, production, warehousing, transportation, and recycling. Green design refers to activities conducted to reduce the negative impact of products and services on the environment during their lifetime (Rostamzadeh et al., 2015). The green design consists of planning where to buy material, how to make the product, and how to dispose of the expired product (Ali et al., 2019). Selection of suitable green materials can minimize bad impacts on the environment, such as the use of prefabricated components that can ease the construction process as well as reduce waste. In addition, the demolition stage is also the result of the material selection process, as it can increase the amount of recycled material and components (Ng, Wong, Skitmore \& Veronika, 2012) so that waste generation, water pollution, carbon emissions, and energy consumption can be minimized (Mitra, 2014).

Green purchasing is when stakeholders involved purchase environment friendly material, such as material with characteristics such as lack of hazardous materials, recyclability, and reusability (Rostamzadah et al., 2015). Moreover, green purchasing requires a high concern for sustainability in the material purchasing process such as cost, quality, and reliability (Eltayeb, Zailani \& Ramayah, 2011). According to Chan (2001), companies are unaware of the fact that green purchasing can reduce production costs and play a role in implementing sustainable policies in all parts of the company.

Green transportation is carried out by the construction sector to reduce adverse environmental impacts associated with transportation activities (BRE, 2003). Six to eight percent of carbon produced during the construction process comes from material transportation (Ng et al., 2012); thus, it is necessary to apply green transportation, such as carry materials via full trucks and using fuel-efficient vehicles. In addition, the use of public transportation for employees, choosing the location of employee shelters close to the project location and the use of technology such as video calls during meetings can reduce the adverse effects of transportation activities (TemaNord, 2010; BRE, 2003). Green transportation can save expenses and substantially contribute to the economic development and sustainability.

The importance of a warehouse cannot be overlooked in the supply chain in all industrial sectors (Bartolini, Bottani \& Grosse, 2019). In every logistic activity, warehouses greatly contribute to the emergence of greenhouse gases; thus, impacting global warming. Warehousing activities account for $11 \%$ of the total greenhouse gases emissions due to logistic activities. Therefore, companies must begin to pay attention, not only to the economic and operational performance of warehousing activities, but also their environmental performance so that green warehousing practices can be developed.

Green construction is a series of processes in which a profitable and competitive industry builds assets (buildings, structures, supporting infrastructure, and the surrounding environment) that can provide benefits, such as improvement in the quality of life and customer satisfaction, flexibility and adaptability for future changes, offering desirable nature and environment, and maximizing the efficient use of resources (OGC, 2000). Green construction in Indonesia has become popular because the government is applying the concept of sustainable development as a national agenda (Wirahadikusumah \& Ario, 2015). According to Balasubramanian and Shukla (2017), green construction refers to on-site practices that aim to minimize the adverse impact on the environment caused by the construction sector. Green construction aims to minimize the pollutants released into the soil, water, and air during the construction stage through continuous improvement (Johansson \& Winroth, 2009). In addition, the integration of green production can help companies to reduce environmental safety costs, reduce material costs, and improve efficiency (Bidgoli, 2010).

Green recycling, also known as reserve logistics, is defined as the practice of reusing a product after the usage period of the product has expired (Rao \& Holt, 2005). Products that have expired will experience one or several green practices, including being reused, recycled, repaired, updated, remanufactured, or disposed (Eltayeb et al., 2011). Green recycling practices can add value to companies and help shape their image as a positive and responsible company (Ali et al., 2019). Blengini (2009) reported that end-of-life management can minimize 
greenhouse gases emissions by approximately $18 \%$ and total energy spent during the life cycle of a building by approximately $30 \%$.

Facilitating green practices must be supported by management so that the implementation of GSCM practices can be realized. Green practices in the construction sector must be supported more strongly than those in other sectors because the supply chain in the construction sector is more complex than others (Balasubramanian \& Shukla, 2017). These practices must be facilitated by all stakeholders (the owner/developer, consultant, contractor, and supplier) in the supply chain. The indicators in each green practice were obtained from the literature review. These indicators were then selected and could be adopted in a construction project context through a preliminary survey, as shown in Table 1.

GSCM Practice

\section{Green Design}

Provision for natural ventilation (GD1)

Provision for natural lightning (GD2)

Integration of photovoltaic panels (GD3)

Consideration for an energy-efficient lighting system (GD4)

Consideration for energy-efficient Heating, Ventilation and AirConditioning (HVAC) systems (GD5)

Consideration of materials with high recycled content (GD6)

Consideration of materials with low embodied energy (GD7)

Provision for the use of prefabricated components (GD8)

Consideration to reduce the use of hazardous materials (GD9)

Provision for wastewater recycling systems (GD10)

Green Purchasing

\begin{tabular}{|l|l|}
\hline Purchasing recycled material (GP1) & Ali et al., 2019 \\
\hline Purchasing nontoxic material (GP2) & Shurab et al., 2018 \\
\hline Purchasing eco-labeled material (GP3) & Shurab et al., 2018 \\
\hline $\begin{array}{l}\text { Suppliers must apply environmental management system (EMS) } \\
\text { to take part in tenders (GP4) }\end{array}$ & Zhu et al., 2005 \\
\hline $\begin{array}{l}\text { Suppliers must have ISO 14001 certification to take part in } \\
\text { tenders (GP5) }\end{array}$ & Shurab et al., 2018; Zhu et al., 2005 \\
\hline $\begin{array}{l}\text { Suppliers must have previous experience in providing green } \\
\text { material to take part in tenders (GP6) }\end{array}$ & Shurab et al., 2018 \\
\hline \begin{tabular}{l} 
Cooperation with suppliers for environmental objectives (GP7) 2019 \\
\hline Green Transportation
\end{tabular} & Zhu et al., 2005 \\
\hline Provision of accommodation to employees near project sites (GT1) & Balasubramanian \& Shukla, 2017; Ali et al., 2019 \\
\hline Use of video conferencing (GT2) & Zhu, Sarkis \& Lai, 2007 \\
\hline $\begin{array}{l}\text { Employees are pushed to use public transport and shared } \\
\text { transport (GT3) }\end{array}$ & Balasubramanian \& Shukla, 2017 \\
\hline \begin{tabular}{l} 
Materials are transported in full truckload quantities (GT4) \\
\hline Materials are transported in fuel-efficient vehicles (GT5)
\end{tabular} & Balasubramanian \& Shukla, 2017 \\
\hline
\end{tabular}

\section{Source}

Balasubramanian \& Shukla, 2017; Shurab et al., 2018; Ali et al., 2019

Balasubramanian \& Shukla, 2017

Balasubramanian \& Shukla, 2017

Balasubramanian \& Shukla, 2017; Shurab et al., 2018

Balasubramanian \& Shukla, 2017; Shurab et al., 2018

Balasubramanian \& Shukla, 2017; Shurab et al., 2018

Balasubramanian \& Shukla, 2017; Ali et al., 2019; Mitra, 2014

Balasubramanian \& Shukla, 2017; Mitra, 2014

Balasubramanian \& Shukla, 2017

Balasubramanian \& Shukla, 2017; Ali et al., 2019

Balasubramanian \& Shukla, 2017; Shurab et al., 2018

Balasubramanian \& Shukla, 2017; Shurab et al., 2018;

Ali et al., 2019

Shurab et al., 2018 


\begin{tabular}{|c|c|}
\hline Green Warehousing & Ali et al., 2019 \\
\hline Effectively sell off used products and scrap components (GW1) & Ali et al., 2019 \\
\hline Effectively sell excess capital equipment (GW2) & Ali et al., 2019 \\
\hline Green Construction & $\begin{array}{l}\text { Balasubramanian \& Shukla, 2017; Shurab et al., 2018; } \\
\text { Ali et al., } 2019\end{array}$ \\
\hline Comprehensive waste management plan for projects (GC1) & Balasubramanian \& Shukla, 2017; Shurab et al. 2018 \\
\hline Use of prefabricated components in projects (GC2) & Balasubramanian \& Shukla, 2017; Shurab et al. 2018 \\
\hline $\begin{array}{l}\text { Use of materials with low embodied energy and high recycled } \\
\text { content (GC3) }\end{array}$ & Balasubramanian \& Shukla, 2017 \\
\hline Reducing the use of hazardous materials (GC4) & Balasubramanian \& Shukla, 2017 \\
\hline Automation is used for on-site construction (GC5) & Balasubramanian \& Shukla, 2017 \\
\hline Fuel-efficient equipment/machinery are used in projects (GC6) & Balasubramanian \& Shukla, 2017; Shurab et al. 2018 \\
\hline Implementation of wastewater recycling technology (GC7) & Shurab et al. 2018 \\
\hline Green Recycling & Balasubramanian \& Shukla, 2017; Ali et al., 2019 \\
\hline Recover scrap from projects at the end of their lifecycle (GR1) & Ali et al., 2019 \\
\hline $\begin{array}{l}\text { Utilize waste produced by others in an innovative, useful, and } \\
\text { effective way (GR2) }\end{array}$ & Ali et al., 2019 \\
\hline $\begin{array}{l}\text { Environmental impact assessment during end-of-life demolition } \\
\text { of projects (GR3) }\end{array}$ & Balasubramanian \& Shukla, 2017 \\
\hline Materials from demolished projects are recycled (GR4) & Balasubramanian \& Shukla, 2017 \\
\hline Facilitating Green Practices & Balasubramanian \& Shukla, 2017; Shurab et al., 2018 \\
\hline EMS \& ISO Certification (FGC1) & Balasubramanian \& Shukla, 2017, Shurab et al. 2018 \\
\hline Environmental training (FGC2) & Balasubramanian \& Shukla, 2017, Shurab et al. 2018 \\
\hline Environmental auditing (FGC3) & Balasubramanian \& Shukla, 2017 \\
\hline Green-related research and development (FGC4) & Balasubramanian \& Shukla, 2017 \\
\hline
\end{tabular}

Table 1. Previous studies on GSCM Practices

\subsection{Green Supply Chain Management Performance}

Performance measurement plays an important role in company success and includes building goals, evaluating performance, and determining future actions (Gunasekaran, Subramanian \& Rahman, 2015). In GSCM, good environmental performance is the main goal; however, implementing GSCM requires a large investment, so companies that focus on only environmental performance have imbalanced risk in short- and long-term financial performance. Organizational performance is relevant to the construction sector because it can provide a long-term and complete picture of the benefits of implementing green practices (Green, Zelbst, Meacham \& Bhadauria, 2012; Setyaning, Wiguna \& Rachmawati, 2020). In this study, GSCM performance was examined as a combination of environmental performance, economic performance, and organizational performance.

The indicators of environmental performance in both manufacturing and construction sectors have similarities (Farida, Handayani \& Wibowo, 2019), such as reduction in the use of hazardous materials, workplace accidents and safety issues, and carbon emissions. Economic performance indicators in both sectors include reducing material costs, waste treatment, and energy use. According to Balasubramanian and Shukla (2017), organizational performance measures relevant to the construction sector include increased revenue, sale prices, market share, investment returns, and profits. 


\subsection{Green Supply Chain Management Framework}

Deros et al. (2006) stated that a framework is a practical guideline for implementation that contains a simplified set of theoretical principles that could be implemented easily and effectively. Some authors have proposed various frameworks in GSCM research. Balasubramanian and Shukla (2017) developed and validated the multidimensional GSCM framework for the construction sector covering all core stages of the supply chain and considering the role of each stakeholder involved at that core stage. Ghobakhloo, Tang, Zulkifli and Ariffin (2013) integrated a variety of pre-existing GSCM frameworks with literature study methods. While Kazancoglu, Kazancoglu and Sagnak (2018) created a comprehensive GSCM performance assessment framework based on circular economy theory consisting of environmental, economic, logistics, operational, organizational, and marketing performance. In general, a framework is developed to improve the implementation of green supply chains. This objective will be influenced by the various clusters and factors and how they are all correlated. These relationships may vary due to assumptions made by the decision-makers and the level of complexity that they wish to model. The relationship among factors is symbolized by the arrows.

For this study, the final result was the creation of a GSCM implementation framework or chart in the construction sector that could improve environmental, economic, and organizational performance. These sub-factors were linked, and the order and weight were determined using AHP analysis and TOPSIS analysis.

\section{Research Methodology}

This study used a quantitative approach that employed primary data gathered from a questionnaire survey. A pilot survey was distributed to three green construction experts with more than 10 years' work experience. They were asked to provide their preferences related to green construction variables to validate the relevant research variables. There were 53 variables listed in the pilot survey, which 14 irrelevant variables were then removed. GSCM practice was used in the main questionnaire if two out of three experts provided relevant answers. Subsequently, the updated questionnaire was then administered to respondents. It tooks around 2 months for data collection. The major obstacle was seeking the respondents as the survey was conducted in the beginning of pandemic situation when many institutions asked their staff to work from home.

The main questionnaire's respondents were stakeholders in building construction projects that had applied the green concept, consisting of five project owners, five persons from planning consultants, five persons from contractor companies, and five persons from supplier companies. Build contract were applied to all observed construction project. Therefore, owner, contractor, planning consultants and supplier are key players in the construction project, which then they were asked to participate in this survey. All respondents had 5-10 years' work experience, which is in accordance with sample profile consideration. According to Hair, Black, Babin, Anderson, \& Tatham (2007), the decision-making group should have a minimum of five members and a maximum of 50. There were five respondents for each stakeholder in this study, with a total of 20 respondents. The respondents were recruited using purposive sampling and snowballing. These methods were selected as respondents had to be experts in green construction projects. In addition, these methods are useful in building a network for specific research when the specific population is yet to be made available (Etikan, Musa \& Alkassim, 2016). In addition, some respondents were recommended by other respondents due to their expertise and roles in construction projects. They were actively involved in four on-going apartment projects.

The questionnaire survey results were analyzed using pairwise comparison (PWC) method and technique for others preference by similarity to ideal (TOPSIS) methods. Pairwise comparison was used to calculate the weight of criteria and TOPSIS was used to rank alternatives consisting of indicators in GSCM practices. Criteria weighting and variable ranking were used to develop a holistic GSCM framework according to construction project life cycle with responsible and relevant stakeholder in each stage.

In this study, pairwise comparison was combined with TOPSIS to obtain more accurate and objective ranking results. The combination of these two methods supported each other, as PWC is suitable for determining the weight and hierarchy of criteria, whereas TOPSIS is able to rank items by applying the concept that the optimal alternative must have the shortest distance from the positive ideal solution and the farthest distance from the 
negative ideal solution. The results obtained from the combination of PWC and TOPSIS methods were able to rank many alternatives, and these were then used to develop the framework. The detail procedure is depicted through flow chart on Figure 1.

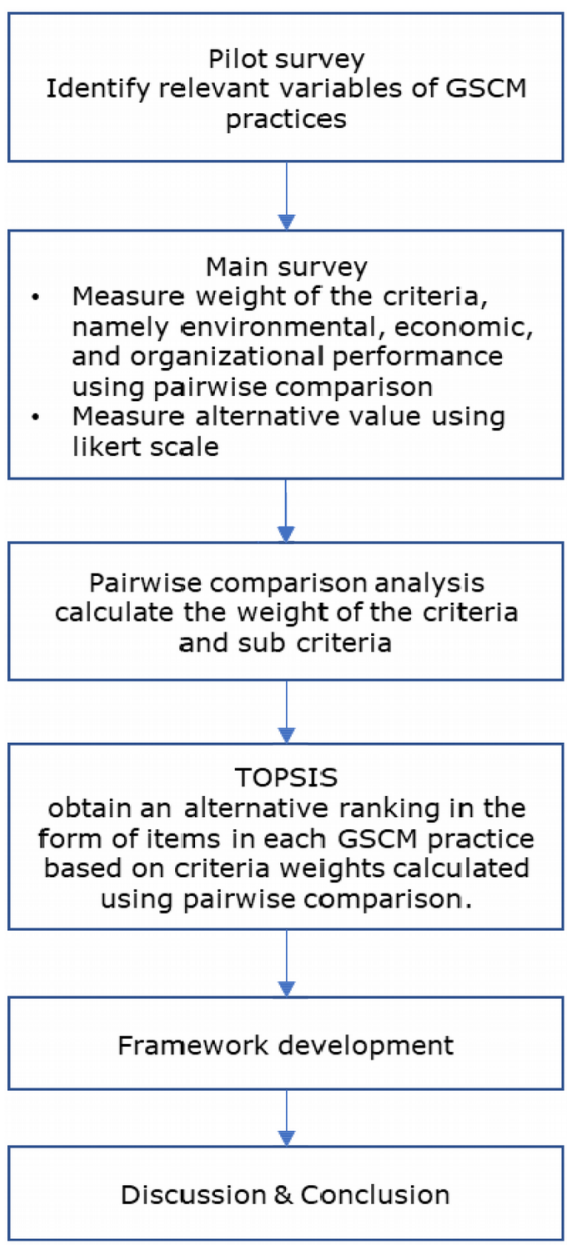

Figure 1. Flow chart

\section{Data Analysis}

\subsection{Weighting Criteria}

Pairwise comparison was used to calculate the weight of the criteria, namely environmental, economic, and organizational performance. The measurements used in the comparison matrix are shown in Table 2.

\begin{tabular}{|c|l|l|}
\hline Intensity & \multicolumn{1}{|c|}{ Definition } & \multicolumn{1}{c|}{ Explanation } \\
\hline 1 & Equal importance & Two activities contribute equally to the object \\
\hline 3 & Moderate importance & Slightly favors one over another \\
\hline 5 & Essential or strong importance & Strongly favors one over another \\
\hline 7 & Demonstrated importance & Dominance of the demonstrated importance in practice \\
\hline 9 & Extreme importance & Evidence favoring one over another with the highest possible affirmation \\
\hline $2,4,6,8$ & Intermediate values & When compromise is needed \\
\hline
\end{tabular}

Table 2. Measurement of Criteria Variables 
The process of weighting the criteria began with compiling the pairwise comparison matrix, normalizing the pairwise comparison matrix, calculating the criteria weight, and checking the consistency of the pairwise comparison matrix by calculating the consistency index and consistency ratio. In the data collection process, respondents were asked to choose more important variable by comparing the importance of two variables. The example of question and option is shown in Figure 2.

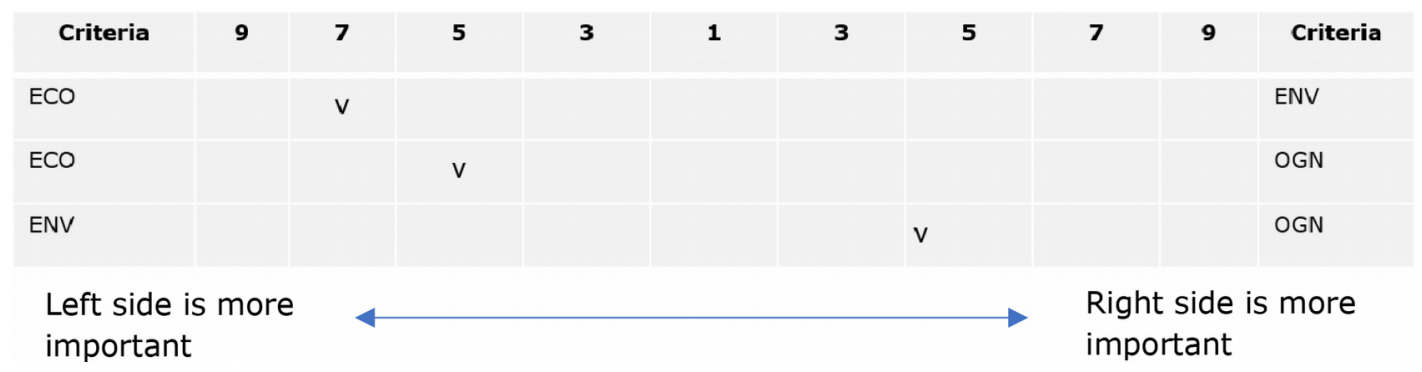

Figure 2. Sample of question

In Figure 2, it exemplifies how to choose the more important between two variables, such as for economy is strongly favors compared to organization, while organization is more favorable than environment.

The detail results of these steps are described in Tables 3-5.

\begin{tabular}{|c|r|r|r|}
\hline Criteria & \multicolumn{2}{|c|}{ Economy } & \multicolumn{2}{|c|}{ Environment } & \multicolumn{2}{c|}{ Organization } \\
\hline Economy & 1 & 1.26 & 0.75 \\
\hline Environment & 0.80 & 1 & 1.04 \\
\hline Organization & 1.34 & 0.96 & 1 \\
\hline
\end{tabular}

Table 3. Pairwise Comparison Matrix

\begin{tabular}{|c|c|c|c|c|}
\hline Criteria & Economy & Environment & Organization & Weight \\
\hline Economy & 0.32 & 0.39 & 0.27 & 0.326 \\
\hline Environment & 0.25 & 0.31 & 0.37 & 0.312 \\
\hline Organization & 0.43 & 0.30 & 0.36 & 0.362 \\
\hline
\end{tabular}

Table 4. Normalized Pairwise Comparison and Criteria Weight

$$
\lambda_{\text {maximal }}=3.034
$$

Consistency test according to Saaty (1994) can be calculated using the formula:

$$
\begin{aligned}
& C I=\frac{\lambda \max -n}{n-1} \\
& C I=\frac{3.034-3}{3-1}=0.017 \\
& C R=\frac{C I}{R I} \\
& C R=\frac{0.017}{0.58}=0.030
\end{aligned}
$$




\begin{tabular}{|c|c|c|c|c|c|c|c|c|c|c|}
\hline $\mathbf{N}$ & 1 & 2 & 3 & 4 & 5 & 6 & 7 & 8 & 9 & 10 \\
\hline $\mathbf{R I}$ & 0 & 0 & 0.58 & 0.9 & 1.12 & 1.24 & 1.32 & 1.41 & 1.45 & 1.49 \\
\hline
\end{tabular}

Table 5. Random Index (RI)

The calculation of the criteria weights show that the weight of the organizational performance criteria was the biggest, at 0.362, followed by the economic performance criteria at 0.326, and finally, the environmental performance criteria, at 0.312 . The weight of each criterion did not differ much, indicating that the economic, environmental and organizational performance criteria were equally important. Meanwhile, the level of pairwise comparison matrix consistency can be seen from the CR value, which was smaller than 0.1 and indicates that pairwise comparison matrix in this study was consistent.

\subsection{Ranking Alternatives}

TOPSIS analysis was used to obtain an alternative ranking in the form of items in each GSCM practice based on criteria weights calculated using pairwise comparison. The variables used in the decision matrix are shown in Table 6.

\begin{tabular}{|c|c|}
\hline Linguistic Variable & Weight \\
\hline Very unimportant & 1 \\
\hline Unimportant & 2 \\
\hline Quite important & 3 \\
\hline Important & 4 \\
\hline Very important & 5 \\
\hline
\end{tabular}

Table 6. Measurement of Alternative Variables

The results of TOPSIS analysis and calculation for ranking items on green design practices are shown in Table 7 . The below calculation was performed for all items in green design practices, and the results are provided in Table 7. The same applies to items in all GSCM practices. Ranking results on other GSCM practices are shown in Table 8.

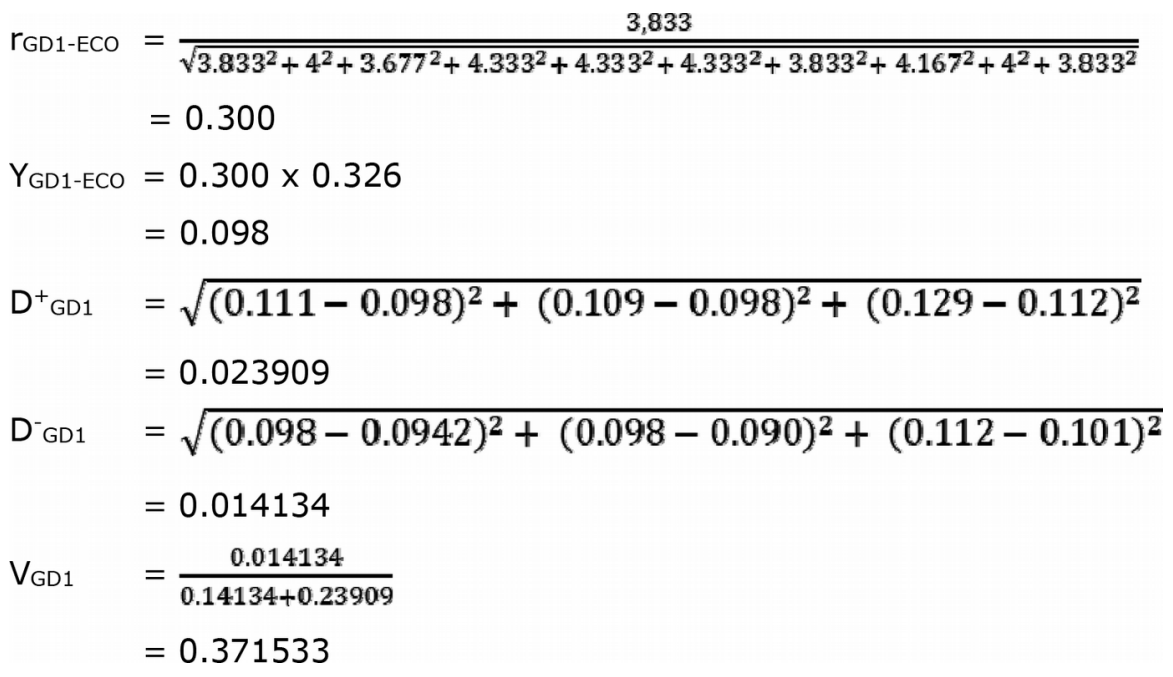




\begin{tabular}{|c|c|c|c|c|c|c|c|c|c|c|c|c|c|}
\hline \multirow{3}{*}{$\begin{array}{l}\text { Green } \\
\text { Design } \\
\text { Items }\end{array}$} & \multicolumn{3}{|c|}{ Decision Matrix } & \multicolumn{3}{|c|}{$\begin{array}{c}\text { Normalized Decision } \\
\text { Matrix }\end{array}$} & \multicolumn{3}{|c|}{$\begin{array}{l}\text { Weighted Normalized } \\
\text { Decision Matrix }\end{array}$} & \multirow[b]{3}{*}{$\mathrm{D}+$} & \multirow[b]{3}{*}{ D- } & \multirow[b]{3}{*}{ V } & \multirow[b]{3}{*}{ Rank } \\
\hline & \multicolumn{3}{|c|}{ Criteria } & \multicolumn{3}{|c|}{ Criteria } & \multicolumn{3}{|c|}{ Criteria } & & & & \\
\hline & ECO & $\mathbf{E N V}$ & OGN & ECO & ENV & OGN & ECO & ENV & OGN & & & & \\
\hline GD1 & 3.833 & 4.333 & 3.333 & 0.300 & 0.313 & 0.309 & 0.098 & 0.098 & 0.112 & 0.023 & 0.014 & 0.3715 & 8 \\
\hline GD2 & 4.000 & 4.500 & 3.333 & 0.313 & 0.325 & 0.309 & 0.102 & 0.102 & 0.112 & 0.020 & 0.018 & 0.4708 & 6 \\
\hline GD3 & 3.667 & 4.167 & 3.000 & 0.287 & 0.301 & 0.278 & 0.094 & 0.094 & 0.101 & 0.036 & 0.003 & 0.0946 & 10 \\
\hline GD4 & 4.333 & 4.000 & 3.500 & 0.339 & 0.289 & 0.325 & 0.111 & 0.090 & 0.117 & 0.021 & 0.023 & 0.5219 & 5 \\
\hline GD5 & 4.333 & 4.333 & 3.667 & 0.339 & 0.313 & 0.340 & 0.111 & 0.098 & 0.123 & 0.012 & 0.029 & 0.6978 & 2 \\
\hline GD6 & 4.333 & 4.500 & 3.333 & 0.339 & 0.325 & 0.309 & 0.111 & 0.102 & 0.112 & 0.018 & 0.023 & 0.5588 & 4 \\
\hline GD7 & 3.833 & 4.333 & 3.333 & 0.300 & 0.313 & 0.309 & 0.098 & 0.098 & 0.112 & 0.023 & 0.014 & 0.3715 & 7 \\
\hline GD8 & 4.167 & 4.167 & 3.833 & 0.326 & 0.301 & 0.355 & 0.106 & 0.094 & 0.129 & 0.015 & 0.031 & 0.6643 & 3 \\
\hline GD9 & 4.000 & 4.833 & 3.667 & 0.313 & 0.350 & 0.340 & 0.102 & 0.109 & 0.123 & 0.010 & 0.030 & 0.7494 & 1 \\
\hline GD10 & 3.833 & 4.500 & 3.000 & 0.300 & 0.325 & 0.278 & 0.098 & 0.102 & 0.101 & 0.031 & 0.012 & 0.2761 & 9 \\
\hline & & & & & & V+ & 0.111 & 0.109 & 0.129 & & & & \\
\hline & & & & & & V- & 0.094 & 0.090 & 0.101 & & & & \\
\hline
\end{tabular}

Table 7. TOPSIS Analysis for Green Design Practices

\begin{tabular}{|c|r|r|}
\hline \multicolumn{2}{|c|}{ V } & \multicolumn{2}{c|}{ Rank } \\
\hline Green Purchasing & 0.1107 & 7 \\
\hline GP1 & 0.1646 & 6 \\
\hline GP2 & 0.3669 & 5 \\
\hline GP3 & 0.8455 & 2 \\
\hline GP4 & 0.9421 & 1 \\
\hline GP5 & 0.7281 & 4 \\
\hline GP6 & 0.7975 & 3 \\
\hline GP7 & 0.7294 & 2 \\
\hline Green Transportation & 0.7376 & 1 \\
\hline GT1 & 0.1579 & 5 \\
\hline GT2 & 0.5040 & 4 \\
\hline GT3 & 0.6982 & 3 \\
\hline GT4 & & \\
\hline GT5 & & \\
\hline Green Warehousing & & \\
\hline GW1 & & \\
\hline GW2 & & \\
\hline & & \\
\hline
\end{tabular}

\begin{tabular}{|c|c|c|}
\hline GSCM Practice & $\mathbf{V}$ & Rank \\
\hline \multicolumn{3}{|l|}{ Green Construction } \\
\hline GC1 & 0.6897 & 1 \\
\hline GC2 & 0.4664 & 2 \\
\hline GC3 & 0.3315 & 5 \\
\hline GC4 & 0.3288 & 6 \\
\hline GC5 & 0.3766 & 4 \\
\hline GC6 & 0.4120 & 3 \\
\hline GC7 & 0.2496 & 7 \\
\hline \multicolumn{3}{|l|}{ Green Recycling } \\
\hline GR1 & 0.2077 & 4 \\
\hline GR2 & 0.8083 & 1 \\
\hline GR3 & 0.3226 & 3 \\
\hline GR4 & 0.6296 & 2 \\
\hline \multicolumn{3}{|c|}{ Facilitating Green Practices } \\
\hline FGC1 & 0.8992 & 1 \\
\hline FGC2 & 0.7816 & 2 \\
\hline FGC3 & 0.3535 & 3 \\
\hline FGC4 & 0.2820 & 4 \\
\hline
\end{tabular}

Table 8. Rankings of GSCM Practices 


\subsection{Proposed GSCM Framework for Construction Sector}

This framework involved main stakeholders as key players on construction project. They are, owner, contractor, planning consultants and supplier which has significant roles in the construction project. Green practices ranked using TOPSIS were used as the basis for creating the framework. This GSCM framework is shown in Table 9. The framework in this study consisted of six core GSCM practices with responsible stakeholders in each practice and one facilitating practice. Responsible stakeholders means that they have major roles in certain GSCM practice, for example in green design, only owner and design consultant who are involved. GSCM practices contained in the framework were based on the highest preference values to improve the economic, environmental, and organizational performances of companies.

From the framework, it can be seen that GSCM starts from green design practices with the owners and design consultants. The black arrow explains the sequence of steps in GSCM according to the project's life cycle. In addition, the black arrow is in accordance with the supply chain at the construction stage, according to Balasubramanian and Shukla (2017), which starts with the flow of information from the owner and consultant to the building design. Following this, the black arrow leads to green purchasing practices with the owners, contractors, and suppliers. After green purchasing practices, the next practice is green transportation performed with the owners, design consultants, contractors, and suppliers. The participating stakeholders in green warehousing practice are contractors and suppliers. After green warehousing practices, the next practice is green construction, and the last is green recycling in which the contractors are the involved stakeholders. Previous research referred to green recycling as reserve logistics, which means waste generated in the construction process can be reused after going through a recycling process. In addition to the six practices in the white box, other practices are no less important, facilitating green practices in the grey box. The practice was place outside of the box because this practice forms the support of the management of each stakeholder for other practices to be carried out properly.

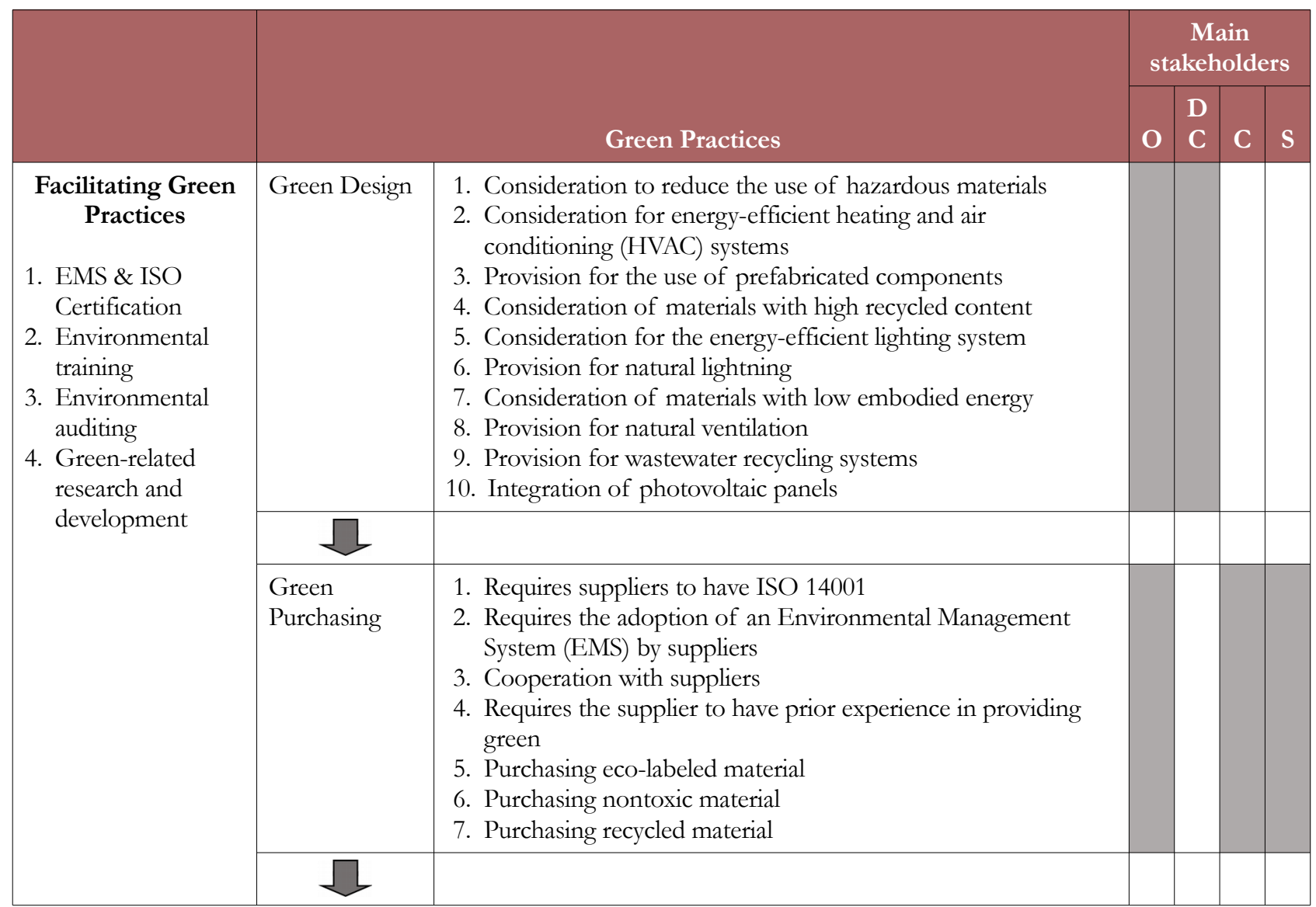




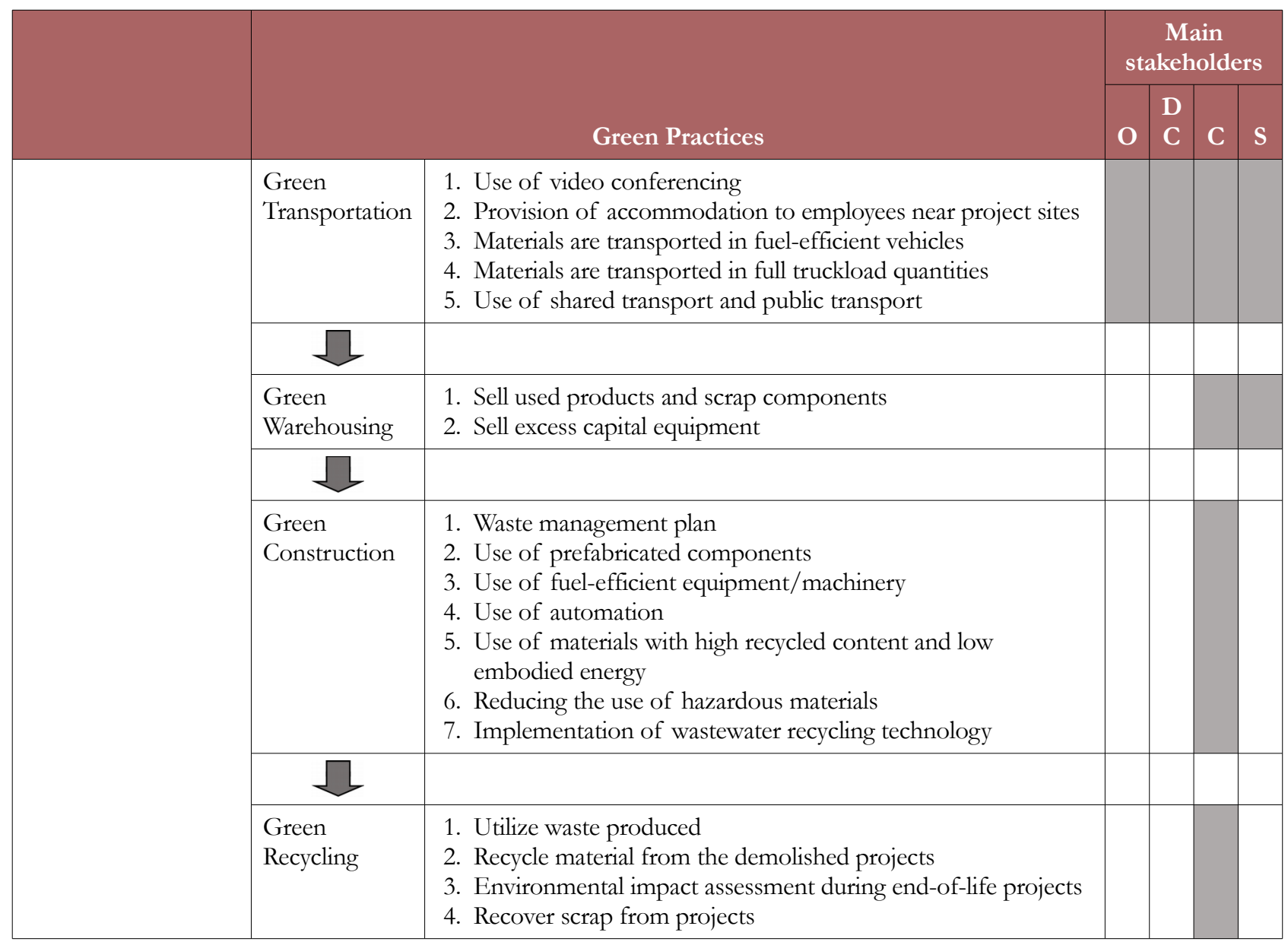

Note: $\mathrm{O}=$ Owner; $\mathrm{DC}=$ Design Consultant; $\mathrm{C}=$ Contractor; $\mathrm{S}=$ Supplier

Table 9. GSCM Framework

\section{Discussion}

The criteria for ranking green practices in the framework were improving the economic, environmental, and organizational performances analyzed using pairwise comparison. The results of the analysis show that the criteria for organizational performance were higher when compared to economic and environmental performance. This is in line with Green et al. (2012), which stated that organizational performance is important and relevant for the construction sector because it can provide a long-term and complete picture of the benefits of implementing green practices. In addition, our results show that improving environmental and economic performances has a positive effect on organizational performance.

To implement GSCM, internal organizational environmental management is required to change activities and processes within the company to be more environmentally friendly (Jabbour \& Jabbour, 2016). This approach was taken in this project by the contractor to improve the environmental management performance of construction projects, including:

1. Management of construction waste during the construction process by providing adequate construction waste storage sites.

2. Sorting out construction waste according to its type.

3. Collaboration with third parties (collectors) and monitoring the volume of waste generated during the construction process.

4. Encouraging the reduction of construction waste generation so that it did not overload the final waste collection site and increasing support for the environment by reusing waste materials. 
5. Emphasizing the 3R concept (reuse, reduce, and recycle) during the construction process and using vendors who already had ISO 14001 certificates.

In green design, the highest preference for improving economic, environmental, and organizational performances lies in consideration to reducing the use of hazardous materials. According to Zhu et al. (2005), in the manufacturing industry, it is important for companies to apply this practice as part of the eco-design to support the implementation of GSCM. The second preference is consideration for using energy-efficient heating and air conditioning (HVAC) systems. As air conditioning is an electronic device that requires considerable electrical energy; thus, the use of energy-efficient HVAC systems can significantly reduce electricity usage.

Meanwhile, in green purchasing, the highest preference was ISO 14001 certification requirement for suppliers in the bidding process. This was in line with the approach taken by the contractor to improve environmental management in construction projects. The second preference requires the implementation of an environmental management system (EMS) by suppliers in order to participate in tenders. The third preference is cooperation with suppliers for environmental objectives. According to Murphy and Bendell (1998), improving the environmental performance of an organization through the implementation of green purchasing is more difficult compared to those in other green practices. Murphy and Bendell (1998) suggested that these difficulties could be solved with the implementation of EMS by suppliers and cooperation with suppliers to increase environmental awareness.

The highest preference in green transportation practice was the use of video conferencing. Recently, the use of video conferencing had became very easy and common. The second preference was the provision of accommodation close to project sites for employees. According to the responses from contractors, supplying temporary shelter for employees, especially daily workers, close to the project site has many benefits for the company, namely that workers rarely come late, workers were not tired from traveling from their home to the project site so they would be more productive, and it was easier for the company to control worker's cleanliness and health. According to Ali et al. (2019), green transportation not only contributes to the project development and economic sustainability but can also save expenses. More importantly, green transportation pushes workers to live a healthy lifestyle. Workers' immune systems could also be strengthened through the reduction of pollution in the environment, especially the work environment

In green warehousing practice in this study, the highest preference was to sell off scrap components and used products and then sold excess capital equipment, as these were the only two green warehousing practices relevant to the construction sector. Green warehousing was gaining attention in working towards cost and energy savings. Green warehousing required a large initial cost, which was a major obstacle to the implementation of this practice. Yet, many companies were implementing this to minimize costs, carbon footprint, and adverse impacts on the environment as a form of social responsibility (Akyelken, 2011).

A comprehensive waste management plan had the highest preference in green construction practice. Ding, Zhu, Tam, Yi and Tran (2018) suggested that the application of construction waste management carried out from the design and construction stage of a project can reduce construction waste by $40.63 \%$ of the total waste that exists. The second preference was to use prefabricated materials in the project. The use of prefabricated materials was the best possible solution to reduce the amount of waste, in both the design and construction stages. The use of prefabricated materials also has other benefits, such as increased quality control, a safer work environment, shortened working time, and reducing the number of workers required to do the work (Jaillon, Poon \& Chiang, 2009).

In green recycling, the highest preference was to utilize waste produced by others in an effective, useful, and innovative way. According to Eltayeb et al. (2011), the reuse of waste in the construction sector can significantly reduce production costs. The second preference was that the material from demolition projects was recycled. A good demolition process would take a holistic approach to the demolishing of buildings that paid attention to the effects of the process on the location of the building and its surrounding property, roads, and environment. A carefully planned and executed demolition with the efficient use of energy was required to maximize the recovery and recycling rates of the material ( $\mathrm{Ng}$ et al., 2012). 
Meanwhile, in facilitating green practices, the highest preference was to apply EMS and ISO 14001 certification. Companies that apply for EMS could identify how operational activities had an impact on the environment and types of environmental impacts that might arise from different operational activities and did a preventive activity to reduce impacts. This finding was in line with study of Darko, Chan, Ameyaw, Owusu, Erika and Edwards (2019). EMS standards for each company were different; thus, it was necessary to apply ISO 14001 as a general standard. Plenty of evidence can be considered by the construction industry stakeholders about the importance of EMS and ISO 14001 (Seuring \& Muller, 2008). The second preference was environmental training, which was very important to increase competence, knowledge and awareness. Employees at all levels in the company, starting with managers (Qi, Shen, Zeng \& Jorge, 2010) and construction workers (Jaillon et al., 2009) must attend this training. For example, Begum, Siwar, Pereira and Jaafar (2009) stated that contractors with employees participating in waste treatment training have better attitudes regarding waste management.

Finally, the implementation of GSCM in the construction sector in Indonesia was more focused on reducing the use of hazardous materials, such as the processing of waste at the project site so that the waste could be reused by both the project itself and other projects through selling products and components that were no longer used, using video conferencing for both inter- and intra-organization meetings, and support from management in the form of the implementation of EMS and the existence of ISO 14001 certification.

This research is expected to complement previous research and contribute to developing the GSCM scientific field in the context of construction project management by providing a framework regarding the implementation of GSCM in the construction sector. The contribution of this study to the existing knowledge of GSCM contributes to the GSCM framework for the construction sector based on a ranking of green practices that must be applied to improve environmental, economic, and organizational performance.

\section{Conclusion and Future Research}

This study revealed the weight of GSCM performance to be implemented in the GSCM framework for the construction field. Based on a PWC analysis in weighting criteria, the organizational performance had a greater weight than environmental and economic performance, indicating that it is more important compared to other performances. However, there were no significant weight differences between the three performances. Seven green practices were found in the GSCM stage: green design, purchasing, transportation, warehousing, construction, recycling, and facilitating green practices. There were 10 items in green design, with reducing the use of hazardous materials the item with the highest ranking. In green purchasing there were seven items, with the highest ranking for requiring suppliers to have ISO 14001 certification to be able to participate in tenders. In green transportation there were five items, and the highest ranking was for use of video conferencing. In green warehousing there were two items, and the highest ranking was selling off used products and scraping components. There were seven items in green construction and comprehensive waste management plan for projects was the highest ranking. In green recycling there were four items, and the highest ranking was utilizing waste produced by others in an effective, useful and innovative way. Finally, there were four items in facilitating green practices, with EMS and ISO Certification the highest ranking. The seven green practices were linked to each other, as stated by Balasubramanian and Shukla (2017); therefore, failure in certain practices will influence others.

This study contributed to knowledge by developing framework which was arranged from relevant variables as major green practices in the context of project with build contract. Furthermore, the findings used to formulate the improvement of GSCM practices in real construction project. This study could be enhanced by adding other GSCM performances as criteria, such as operational and logistical performances and adding sub-criteria for these. More respondents would also enrich the study. Further research could be directed on the evaluation of the implementation of a GSCM framework in construction projects. This study used case study construction projects in Indonesia. However, to a larger extent, the findings of this study could be adapted and applied to other construction projects in other countries using build contract and initiate GSCM in the construction sector, as it will involve similar stakeholders and typical green practices. 


\section{Declaration of Conflicting Interests}

The authors declare no potential conflicts of interest with respect to the research, authorship, and/or publication of this article.

\section{Funding}

This paper is a part of the "Green Supply Chain Management Framework for Construction Sector" research. The researchers acknowledge the Institut Teknologi Sepuluh Nopember, who provided funding for this research.

\section{References}

Abas, M., Khattak, S.B., Tufail, H., \& Nadir, U. (2020). Assessment of critical risk and success factors in construction supply chain: A case of Pakistan. International Journal of Construction Management, 1-9. https://doi.org/10.1080/15623599.2020.1783597

Akyelken, N. (2011). Green Logistics: Improving the Environmental Sustainability of Logistics. Transport Reviens, 31(4), 547-548. https://doi.org/10.1080/01441647.2010.537101

Ali, Y., Saad, T.B., Sabir, M., Muhammad, N., Salman, A., \& Zeb, K. (2019). Integration of green supply chain management practices in construction supply chain of CPEC. Management of Environmental Quality, 31(1), 185-200. https://doi.org/10.1108/MEQ-12-2018-0211

Alvarez, G.M.J., Jimenez, J.B., \& Lorente, J.C. (2001). An analysis of environmental management, organizational context and performance of Spanish hotels. Omega, 29(6), 457-471. https://doi.org/10.1016/S0305-0483(01)00033-0

Balasubramanian, S., \& Shukla, V. (2017). Green supply chain management: An empirical investigation on the construction sector. Supply Chain Management, 22(1), 58-81. https://doi.org/10.1108/SCM-07-2016-0227

Bappenas (Body of National Development Planning) (2014). Konektivitas infrastruktur wilayah dan antar wilayah.

Bartolini, M., Bottani, E., \& Grosse, E.H. (2019). Green warehousing: Systematic literature review and bibliometric analysis. Journal of Cleaner Production, 226, 242-258. https://doi.org/10.1016/j.jclepro.2019.04.055

Begum, R.A., Siwar, C., Pereira, J.J., \& Jaafar, A.H. (2009). Attitude and behavioral factors in waste management in the construction industry of Malaysia. Resources, Conservation and Recycling, 53(6), 321-328.

https://doi.org/10.1016/j.resconrec.2009.01.005

Bidgoli, H. (2010). The Handbook of Technology Management, Supply chain Management, Marketing and Advertising, and Global Management (2). John Wiley \& Sons and California State University.

Blengini, G.A. (2009). Life cycle of buildings, demolition and recycling potential: A case study in Turin, Italy. Building Environment, 44(2), 319-330. https://doi.org/10.1016/j.buildenv.2008.03.007

Bowen, F.E., Cousins, P.D., Lamming, R.C., \& Faruk, A.C. (2001). Horse for courses: Explaining the gap between the theory and practice of green supply. Greener Management International, 35, 41-60.

https://doi.org/10.9774/GLEAF.3062.2001.au.00006

BRE (2003). Construction Site Transport. Departmen of Trade and Industry, UK.

Budiarto, D.S., Prabowo, M.A., \& Herawan, T. (2017). An integrated information system to support supply chain management \& performance in SMEs. Journal of Industrial Engineering and Management, 10(2), 373-387. https://doi.org/10.3926/jiem.2180

Chan, R.Y. (2001). Determinants of Chinese consumers' green purchase behavior. Psychology and Marketing, 18(4), 389-413. https://doi.org/10.1002/mar.1013

Cooper, C., Douglas, M.L., Martha, \& Pagh, J.D. (1997). Supply chain management: More than a new name for logistics. International Journal of Logistics Management, 8(1), 1-14. https://doi.org/10.1108/09574099710805556 
Darko, A., Chan, A.P.C., Ameyaw, E.E., Owusu, E.K., Erika, P., \& Edwards, D.J. (2019). Review of application of analytic hierarchy process (AHP) in construction. International Journal of Construction Management, 19(5), 436-452. https://doi.org/10.1080/15623599.2018.1452098

Deros, B.M., Yusof, S.M., \& Salleh, A.M. (2006). A benchmarking implementation framework for automotive manufacturing SMEs. Benchmarking an International Journal, 13(4), 396-430.

https://doi.org/10.1108/14635770610676272

Ding, Z., Zhu, M., Tam, V.W.Y., Yi, G., \& Tran, C.N.N. (2018). A system dynamics-based environmental benefit assessment model of construction waste reduction management at the design and construction stages. Journal of Cleaner Production, 176, 676-692. https://doi.org/10.1016/j.jclepro.2017.12.101

Eltayeb, T.K., Zailani, S., \& Ramayah, T. (2011). Green supply chain initiatives among certified companies in Malaysia and environmental sustainability: Investigating the outcomes. Resources, Conservation and Recycling, 55(5), 495-506. https://doi.org/10.1016/j.resconrec.2010.09.003

Etikan, I., Musa, S.A., \& Alkassim, R.S. (2016). Comparison of Convenience Sampling and Purposive Sampling. American Journal of Theoretical and Applied Statistics, 5(1), 1-4. https://doi.org/10.11648/j.ajtas.20160501.11

Farida, N., Handayani, N.U., \& Wibowo, M.A. (2019). Developing indicators of green construction of Green Supply Chain Management in construction industry: A literature review. In: Annual Conference on Industrial and System Engineering (ACISE). https://doi.org/10.1088/1757-899X/598/1/012021

Green, K.W., Zelbst, P.J., Meacham, J., \& Bhadauria, V.S. (2012). Green supply chain management practices: Impact on performance. Supply Chain Management, 17(3), 290-305. https://doi.org/10.1108/13598541211227126

Ghobakhloo, M., Tang, S.H., Zulkifli, N., \& Ariffin, M.K.A. (2013). An integrated framework of green supply chain management implementation. International Journal of Innovation, Management and Technology, 4(1), 86.

Gunasekaran, A., Subramanian, N., \& Rahman, S. (2015). Green supply chain collaboration and incentives: Current trends and future directions. Transportation Research. Part E, Logistics and Transportation Review, 74(C). 1-10. https://doi.org/10.1016/j.tre.2015.01.002

Hair, J.F., Black, W.C., Babin, B.J., Anderson, R.E., \& Tatham, R.L. (2007). Multivariate data analysis. Upper Saddle River, NJ: Prentice Hall.

Hardiani, N. (2016). Faktor-faktor yang mempengarubi penerapan Green Procurement dalam proses pengadaan material konstruksi di Indonesia. Tesis Magister. Institut Teknologi Sepuluh Nopember, Surabaya.

Harty, C. (2008). Implementing innovation in construction: Contexts, relative boundedness and actor-network theory. Construction Management and Economics, 26(10), 1029-1041. https://doi.org/10.1080/01446190802298413

Hervani, A.A., Helms, M.M., \& Sarkis, J. (2005). Performance measurement for green supply chain management. Benchmarking: an International Journal, 12(4), 330-353. https://doi.org/10.1108/14635770510609015

Jabbour, C.J.C., \& Jabbour, A.B.L.D.S. (2016). Green human resource management and green supply chain management: linking two emerging agendas. Journal of Cleaner Production, 112, 1824-1833.

https://doi.org/10.1016/j.jclepro.2015.01.052

Jaillon, L., Poon, C.S., \& Chiang, Y.H. (2009). Quantifying the waste reduction potential of using prefabrication in building construction in Hong Kong. Waste Management, 29(1), 309-320.

https://doi.org/10.1016/j.wasman.2008.02.015

Johansson, G., \& Winroth, M. (2009). Lean vs green manufacturing: Similarities and differences. In Proceedings of the 16th International Annual EurOMA Conference, Implementation Realizing Operations Management Knowledge.

Jung, J.J. (2011). A bibliometric analysis on Green Supply Chain Management: A preliminary result. In Proceedings of the IEEE 13 $3^{\text {th }}$ Conference on Commerce and Enterprise Computing (418-420). https://doi.org/10.1109/CEC.2011.68 
Kazancoglu, Y., Kazancoglu, I., \& Sagnak, M. (2018). A new holistic conceptual framework for green supply chain management performance assessment based on circular economy. Journal of Cleaner Production, 195, 1282-1299. https://doi.org/10.1016/j.jclepro.2018.06.015

Laari, S., Teoyli, J., Solakivi, T., \& Ojala, L. (2016). Firm performance and customer-driven green supply chain management. Journal of Cleaner Production. 112(3), 1960-1970. https://doi.org/10.1016/j.jclepro.2015.06.150

Le, T.T. (2020). The effect of green supply chain management practices on sustainability performance in Vietnamese construction materials manufacturing enterprises. Uncertain Supply Chain Management, 8(1), 43-54. https://doi.org/10.5267/j.uscm.2019.8.007

Li, S.C.M.L. (2007). Supply Chain Management: Concepts, techniques and practices. Enhancing value through collaboration. World Scientific Publishing Co. Pte. Ltd. https://doi.org/10.1142/6273

Mitra, S. (2014). A framework for research on green supply chain management. Supply Chain Forum, 15, 34-51. https://doi.org/10.1080/16258312.2014.11517332

Mohanty, R.P., \& Prakash, A. (2013). Green supply chain management practices in India: an empirical study. Production Planning \& Control, 25(16), 1322-1337. https://doi.org/10.1080/09537287.2013.832822

Murphy D.F., \& Bendell J. (1998). Do it yourself or do it together? The implementation of sustainable timber purchasing policies by DIY retailers in the UK. In Greener Purchasing. Opportunities And Innovations (118-134). https://doi.org/10.9774/GLEAF.978-1-909493-03-2_11

Ng, S.T., Wong, J.M.W., Skitmore, S., \& Veronika, A. (2012). Carbon dioxide reduction in the building life cycle: A critical review. Engineering Sustainability, 165(4), 281-292. https://doi.org/10.1680/ensu.11.00005

Nurunnabi, M. (2016). Who cares about climate change reporting in developing countries? The market response to, and corporate accountability for, climate change in Bangladesh. Environment, Development and Sustainability, 18(1), 157-186. https://doi.org/10.1007/s10668-015-9632-3

OGC (Office of Government Commerce) (2000). Achieving sustainability in construction procurement. Sustainability Action Group of the Government Construction Client's Panel (GCCP), UK.

Qi, G.Y., Shen, L.Y., Zeng, S.X., \& Jorge, O.J. (2010). The drivers for contractors' green innovation: An industry perspective. Journal of Cleaner Production, 18, 1358-1365. https://doi.org/10.1016/j.jclepro.2010.04.017

Rao, P., \& Holt, D. (2005). Do green supply chains lead to competitiveness and economic performance? International Journal of Operations and Production Management, 25 9), 898-916. https://doi.org/10.1108/01443570510613956

Rezgui, Y., \& Miles, J. (2009). Exploring the potential of SME alliances in the construction sector. Journal of Construction Engineering and Management, 136(5), 558-567. https://doi.org/10.1061/(ASCE)CO.1943-7862.0000150

Rostamzadeh, R., Govindan, K., Esmaeili, A., \& Sabaghi, M. (2015). Application of fuzzy vikor for evaluation of green supply chain management practices. Ecological Indicators, 49(11), 188-203.

https://doi.org/10.1016/j.ecolind.2014.09.045

Saaty, T.L. (1994). Highlights and critical points in the theory and application of the Analytic Hierarchy Process. European Journal of Operational Research, 74(3), 426-447. https://doi.org/10.1016/0377-2217(94)90222-4

Saputra, R. (2015). Pengarub Green Supply Chain Management terhadap kinerja biaya pada perusahaan konstruksi dengan pendekatan Sistem Dinamis. Tesis Magister. Institut Teknologi Sepuluh Nopember, Surabaya.

Setyaning, L.B., Wiguna, I.P.A., \& Rachmawati, F. (2020). Developing activities of green design, green purchasing, and green transportation as the part of green supply chain management in construction sector. IOP Conference Series: Materials Science and Engineering (930 012001). https://doi.org/10.1088/1757-899X/930/1/012001

Seuring, S., \& Müller, M. (2008). From a literature review to a conceptual framework for sustainable supply chain management. Journal of Cleaner Production, 16(15), 1699-1710. https://doi.org/10.1016/j.jclepro.2008.04.020 
Shipeng, L. (2011). A study on green supply chain management of enterprises based on self-locking theory. In Proceedings of International Conference on E-Business and E-Government (ICEE) (1-4). https://doi.org/10.1109/ICEBEG.2011.5881683

Shurrab, J., Hussain, M., \& Khan, M. (2018). Green and sustainable practices in the construction industry: A confirmatory factor analysis approach. Engineering, Construction and Architectural Management. 26(6), 1063-1086. https://doi.org/10.1108/ECAM-02-2018-0056

Singh, A., \& Misra, S.C. (2020). Ordering drivers of green supply chain management practices in Indian construction industry: An impact assessment framework. International Journal of Quality \& Reliability Management. https://doi.org/10.1108/IJQRM-03-2019-0076

Simatupang, T.M., \& Sridharan, R. (2016). A critical analysis of supply chain issues in construction heavy equipment. International Journal of Construction Management, 16(4), 326-338.

https://doi.org/10.1080/15623599.2016.1142250

TemaNord (2010). Innovative green public procurement of construction, IT and transport services in Nordic Countries. Nordic Council of Ministers.

UN Global Compact (2010). Supply Chain Sustainability: A practical guide for continuous improvement. UN Global Compact Office and Business for Social Responsibility.

UNEP (United Nations Environmental Programme), \& SBCI (Sustainable Buildings and Climate Iniciative) (2016). Buildings and Climate Change: Summary for Decision Makers. United Nations Environment Programme.

Walker, H., Sisto, L.D., \& Bain, D.M. (2008). Drivers and barriers to environmental Supply Chain Management practices: Lessons from the public and private sectors. Journal of Purchasing and Supply Management, 14(1), 69-85. https://doi.org/10.1016/j.pursup.2008.01.007

Wirahadikusumah, R.D., \& Ario, D. (2015). A readiness assessment model for Indonesian contractors in implementing sustainability principles. International Journal of Construction Management, 15(2), 126-136. https://doi.org/10.1080/15623599.2015.1033817

Wibowo, M.A., Handayani, M.U., \& Mustikasari, A. (2018). Factors for implementing green supply chain management in the construction industry. Journal of Industrial Engineering and Management, 11(4), 651-679. https://doi.org/10.3926/jiem.2637

Winch, G.M. (2010). Managing construction projects: An information processing approach (2nd ed.). John Wiley \& Sons.

Zaid, A.A., Jaaron, A.A. M., Talib B., \& Abdul J. (2018). The impact of green human resource management and green supply chain management practices on sustainable performance: An empirical study. Journal of Cleaner Production, 204, 965-979. https://doi.org/10.1016/j.jclepro.2018.09.062

Zhu, Q., \& Cote, R.P. (2004). Integrating green supply chain management into an embryonic eco-industrial development: A case study of the guitang group. Journal of Cleaner Production, 12, 1025-1035.

https://doi.org/10.1016/j.jclepro.2004.02.030

Zhu, Q., \& Sarkis, J. (2004). Relationships between operational practices and performance among early adopters of green supply chain management practices in Chinese manufacturing enterprises. Journal of Operation Management, 22(3), 265-289. https://doi.org/10.1016/j.jom.2004.01.005

Zhu, Q., Sarkis, J., \& Geng, Y. (2005). Green supply chain management in China: Pressures, practices and performance. International Journal of Operations and Production Management, 25(5), 449-468. https://doi.org/10.1108/01443570510593148

Zhu, Q., Sarkis, J., \& Lai, K.H. (2007). Green supply management: Pressures, practices and performance within the Chinese automobile industry. Journal of Cleaner Production, 15, 1041-1052.

https://doi.org/10.1016/j.jclepro.2006.05.021 
Zhu, Q., Sarkis, J., \& Lai, K. (2008). Confirmation of a measurement model for green supply chain management practices implementation. International Journal of Production Economics, 111(2), 261-273.

https://doi.org/10.1016/j.ijpe.2006.11.029

Zhu, Q., Geng, Y., \& Lai, K.H. (2011). Environmental supply chain cooperation and its effect on the circular economy practice: Performance relationship among Chinese manufacturers. Journal of Industrial Ecology, 15(3), 405-419. https://doi.org/10.1111/j.1530-9290.2011.00329.x

Zulfikar, M. (2020). Model pengaruh Green Construction terbadap pengurangan limbah konstruksi nerbasis Sistem Dinamik. Tesis Magister. Institut Teknologi Sepuluh Nopember.

Journal of Industrial Engineering and Management, 2021 (www.jiem.org)

\section{(c) $(1) \circledast$}

Article's contents are provided on an Attribution-Non Commercial 4.0 Creative commons International License. Readers are allowed to copy, distribute and communicate article's contents, provided the author's and Journal of Industrial Engineering and Management's names are included. It must not be used for commercial purposes. To see the complete license contents, please visit https://creativecommons.org/licenses/by-nc/4.0/. 